\title{
Modestobacter marinus sp. nov., a psychrotolerant actinobacterium from deep-sea sediment, and emended description of the genus Modestobacter
}

Correspondence

Jun Xu

xu.junn@gmail.com
Jing Xiao, ${ }^{1,2} \dagger$ Yingxue Luo, ${ }^{1} \dagger$ Jing $X u,{ }^{1}$ Shujie $X i{ }^{1}$ and Jun $X u^{3,4}$

${ }^{1}$ Key Laboratory of Marine Biogenetic Resources, The Third Institute of Oceanography SOA, Xiamen, Fujian, 361005, PR China

${ }^{2}$ Division of Integrative Environmental Sciences, Graduate School of Life and Environmental Sciences, University of Tsukuba, Tsukuba, Ibaraki 305-8572, Japan

${ }^{3}$ College of Life Science \& Tech., Shanghai Jiaotong University, Shanghai 200240, PR China

${ }^{4}$ State Key Laboratory of Ocean Engineering, Shanghai Jiaotong University, Shanghai 200240, PR China

The taxonomic status of an actinobacterium that changed colour during growth, strain $42 \mathrm{H} 12-1^{\top}$, isolated from deep-sea sediment collected from the Atlantic Ocean, was established using a combination of genotypic and phenotypic data. Strain $42 \mathrm{H} 12-1^{\top}$ formed a distinct branch in the 16S rRNA gene phylogenetic tree together with the type strains in the genus Modestobacter. The highest sequence similarity by BLAST analysis was to Modestobacter versicolor CP153-2 ${ }^{\top}$ $(98.5 \%)$ and the second-highest sequence similarity was to Modestobacter multiseptatus AA-826 ${ }^{\top}(97.5 \%)$. DNA-DNA relatedness of only $12 \%$ (SD $1.82 \%$ ) between strain $42 \mathrm{H} 12-1^{\top}$ and $M$. versicolor DSM $16678^{\top}$ differentiated them as members of separate genomic species. Colonies of strain $42 \mathrm{H} 12-1^{\top}$ were black on oligotrophic medium, but orange to red, turning black, on copiotrophic medium. The peptidoglycan contained meso-diaminopimelic acid. The polar lipids were diphosphatidylglycerol, phosphatidylethanolamine, phosphatidylglycerol, phosphatidylinositol and an unknown aminophospholipid. The predominant menaquinone was MK-9 $\left(\mathrm{H}_{4}\right)$. The major fatty acids were iso- $\mathrm{C}_{16: 0}$ and $\mathrm{C}_{17: 1} \omega 8 \mathrm{c}$. The DNA $\mathrm{G}+\mathrm{C}$ content was $72.3 \pm 1 \mathrm{~mol} \%$. Strain $42 \mathrm{H} 12-1^{\top}\left(=\mathrm{DSM} 45201^{\top}=\right.$ CGMCC $\left.4.5581^{\top}\right)$ is assigned as the type strain of a novel species of the genus Modestobacter, for which the name Modestobacter marinus sp. nov. is proposed.
Modestobacter multiseptatus (Mevs et al., 2000) and Modestobacter versicolor (Reddy et al., 2007) are Grampositive, non-spore-forming, short-rod- or coccoid-shaped psychrophilic actinobacteria that belong to the family Geodermatophilaceae (Normand, 2006). The former was isolated from Antarctic surface soil from the Linnaeus Terrace $(1600 \mathrm{~m})$ in the Asgard Range/Transantarctic Mountains. The latter was isolated from a biological soil crust sample collected from the Colorado Plateau, USA. Here, we report the polyphasic characterization of strain $42 \mathrm{H} 12-1^{\mathrm{T}}$, which is considered to represent a novel species of the genus Modestobacter.

†These authors contributed equally to this work.

The GenBank/EMBL/DDBJ accession number for the $16 \mathrm{~S}$ rRNA gene sequence of strain $42 \mathrm{H} 12-1^{\top}$ is EU181225.

Four supplementary figures and a supplementary table are available with the online version of this paper.
Strain $42 \mathrm{H} 12-1^{\mathrm{T}}$ was isolated from a deep-sea sediment sample $(2983 \mathrm{~m})$ collected from the Atlantic Ocean $\left(14.7518^{\circ} \mathrm{N} 44.9782^{\circ} \mathrm{W}\right)$. The $16 \mathrm{~S}$ rRNA gene was amplified from a single colony of the isolate using universal primers and PCR conditions as described by Chun \& Goodfellow (1995). The almost-complete 16S rRNA gene sequence $(1483 \mathrm{nt})$ of strain $42 \mathrm{H} 12-1^{\mathrm{T}}$ was obtained and analysed using BLAST searches against the GenBank and EzTaxon databases (Altschul et al., 1997; Chun et al., 2007). The 16S rRNA gene sequences of closely related taxa obtained from GenBank were aligned using CLUSTAL_X (Thompson et al., 1997). Phylogenetic trees were reconstructed by using the maximum-parsimony (Kumar et al., 2004) and neighbour-joining (Saitou \& Nei, 1987) methods with MEGA 3.1 software. The topologies of the trees were evaluated by performing a bootstrap analysis (Felsenstein, 1985) using 1000 replications.

The 16S rRNA gene sequence comparison clearly showed that strain $42 \mathrm{H} 12-1^{\mathrm{T}}$ belonged to the genus Modestobacter 
and formed a distinct subclade with M. versicolor CP153-2 ${ }^{\mathrm{T}}$ (Fig. 1 and Supplementary Fig. S1, available in IJSEM Online). The 16S rRNA gene sequence similarities between strain $42 \mathrm{H} 12-1^{\mathrm{T}}$ and $M$. versicolor $\mathrm{CP} 153-2^{\mathrm{T}}$ and $M$. multiseptatus AA- $826^{\mathrm{T}}$ were 98.5 and $97.5 \%$, respectively. Lower 16S rRNA gene sequence similarities were recorded with strains of species of Blastococcus and Geodermatophilus (also in the family Geodermatophilaceae), such as Blastococcus jejuensis KST3-10 $10^{\mathrm{T}}(96.4 \%)$, Blastococcus saxobsidens $\mathrm{BC} 444^{\mathrm{T}}$ (96.0\%), Blastococcus aggregatus ATCC $25902^{\mathrm{T}}$ (95.6\%), Geodermatophilus obscurus DSM $43160^{\mathrm{T}}(94.2 \%)$ and Geodermatophilus ruber CPCC $201356^{\mathrm{T}}$ (95.0\%).

The reference strains $M$. versicolor DSM $16678^{\mathrm{T}}$ and $M$. multiseptatus DSM $44406^{\mathrm{T}}$ were obtained from the German Collection of Microorganisms and Cell Cultures (DSMZ, Braunschweig, Germany). M. versicolor DSM $16678^{\mathrm{T}}$ was maintained on modified ISP2 medium (International Streptomyces Project medium 2; $0.4 \%$ glucose, $0.4 \%$ yeast extract, $1 \%$ malt extract, $\mathrm{pH} 7.0-7.2)$ at $28{ }^{\circ} \mathrm{C}$ and $M$. multiseptatus DSM $44406^{\mathrm{T}}$ was grown on R2A (DSMZ medium 830) at $20{ }^{\circ} \mathrm{C}$.

There were obvious morphological differences between strain $42 \mathrm{H} 12-1^{\mathrm{T}}$ and $M$. multiseptatus DSM $44406^{\mathrm{T}}$. M. multiseptatus DSM $44406^{\mathrm{T}}$ did not grow on ISP2 or trypticase soy agar (TSA). Growth of $M$. multiseptatus DSM $44406^{\mathrm{T}}$ was visible after 20 days on $\mathrm{R} 2 \mathrm{~A}$ at $20{ }^{\circ} \mathrm{C}$, but only as a thin lawn. In contrast, strain $42 \mathrm{H} 12-1^{\mathrm{T}}$ grew well on both ISP2 and TSA plates within 7 days at $28{ }^{\circ} \mathrm{C}$. The maximum temperature for growth of $M$. multiseptatus DSM $44406^{\mathrm{T}}$ was $28^{\circ} \mathrm{C}$, while that of strain $42 \mathrm{H} 12-1^{\mathrm{T}}$ was $35{ }^{\circ} \mathrm{C}$. The obvious differences stated above support the conclusion that they represent different species.

Morphological characteristics of cells from exponentially growing cultures were observed by light microscopy (Olympus microscope CX21) and transmission electron microscopy (JEOL JEM-1230). Strain $42 \mathrm{H} 12-1^{\mathrm{T}}$ and $M$. versicolor DSM $16678^{\mathrm{T}}$ were grown on rich medium (ISP2) and oligotrophic medium (1/10-strength ISP2; $0.04 \%$ glucose, $0.04 \%$ yeast extract, $0.1 \%$ malt extract, $\mathrm{pH} 7.0$ 7.2 ), and the colours of the colonies were observed after incubating for $2,4,6,10,15$ and 30 days at $28{ }^{\circ} \mathrm{C}$. The temperature for growth was tested at $4,10,20,28,30,35$ and $37{ }^{\circ} \mathrm{C}$ on ISP2 agar over 15 days, while the $\mathrm{pH}$ for growth was investigated between $\mathrm{pH} 3.0$ and 11.0 at intervals of $1 \mathrm{pH}$ unit at $28{ }^{\circ} \mathrm{C}$ over 15 days using ISP2 broth with different buffers as described by $\mathrm{Xu}$ et al. (2005). $\mathrm{NaCl}$ tolerance was tested at $0-15 \% \mathrm{NaCl}(\mathrm{w} / \mathrm{v})($ at intervals of $1 \%$ ) using ISP2 broth at $28{ }^{\circ} \mathrm{C}$ over 15 days.

Gram staining was carried out by using the standard Gram reaction and was confirmed by using the $\mathrm{KOH}$ lysis test (Cerny, 1978). Catalase activity was determined using 3\% $\mathrm{H}_{2} \mathrm{O}_{2}$. Oxidase activity was observed by oxidation of tetramethyl-p-phenylenediamine. Biochemical tests such as nitrate reduction, indole production, glucose fermentation, arginine dihydrolase, urease, $\beta$-glucosidase, gelatin hydrolysis and $\beta$-galactosidase were performed using an API 20NE kit (bioMérieux) and enzyme activities were determined using an API ZYM kit (bioMérieux) according to the manufacturer's instructions. Carbon assimilation and oxidation were determined using API 20NE and API 50CH kits (bioMérieux). Sensitivity to different antibiotics was determined by using antimicrobial susceptibility discs. Physiological properties are given in the species description and are compared with those of M. versicolor DSM $16678^{\mathrm{T}}$ in Table 1.

Colonies of $M$. versicolor DSM $16678^{\mathrm{T}}$ were initially colourless to pink and turned dark with incubation over 2-4 days on oligotrophic complex medium, whereas the colonies remained colourless or pink until a melanin-like pigment was produced in the stationary phase (after 2 weeks) on a rich complex medium (Reddy et al., 2007). Colour-change tests on copiotrophic medium (ISP2) and oligotrophic medium (1/10-strength ISP2) for strain 42H12$1^{\mathrm{T}}$ were observed for 2-30 days with $M$. versicolor DSM $16678^{\mathrm{T}}$ as a comparison. Strain $42 \mathrm{H} 12-1^{\mathrm{T}}$ showed a similar pattern of colony colour change to $M$. versicolor DSM $16678^{\mathrm{T}}$ on oligotrophic medium, but colonies of strain 42H12- ${ }^{\mathrm{T}}$ were deep-orange, whereas those of $M$. versicolor DSM $16678^{\mathrm{T}}$ were pink. After 3 days, both strains started to turn darker, but the speed of melanin-like pigment production in strain $42 \mathrm{H} 12-1^{\mathrm{T}}$ was noticeably greater. After 15 days, colonies of the two strains had changed colour completely to black, but the amount of melanin-like pigment produced in strain $42 \mathrm{H} 12-1^{\mathrm{T}}$ was markedly greater than in M. versicolor DSM $16678^{\mathrm{T}}$ (Supplementary Fig. S2).

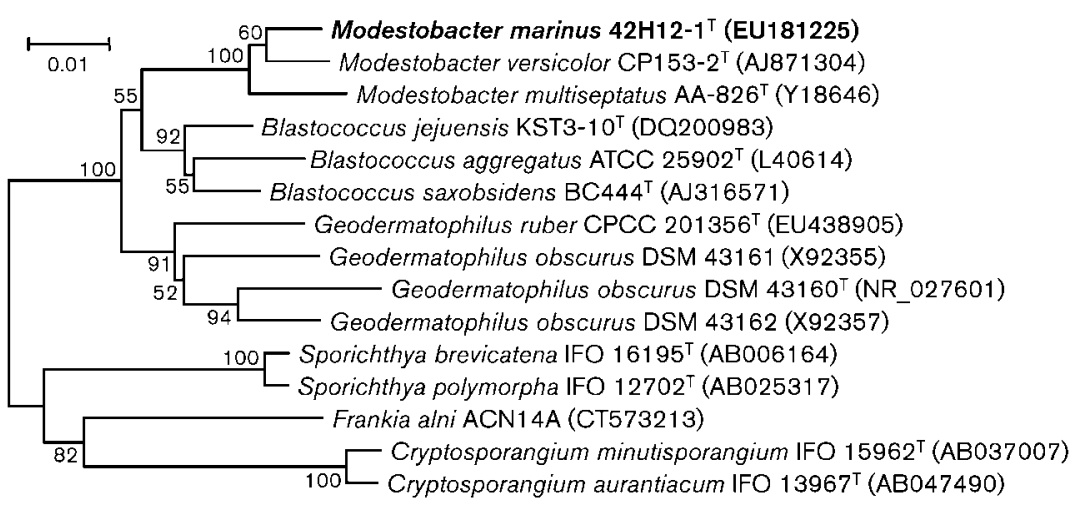

Fig. 1. Phylogenetic dendrogram obtained by distance-matrix analysis of 16S rRNA gene sequences (1402 nt), showing the position of strain $42 \mathrm{H} 12-1^{\top}$ and its phylogenetic neighbours. Bootstrap values are expressed at branch points as percentages of 1000 replications; only values above $50 \%$ are shown. Bar, 0.01 substitutions per nucleotide position. 
Table 1. Characteristics that distinguish strain $42 \mathrm{H} 12-1^{\top}$ from $M$. versicolor DSM $16678^{\top}$

Data were obtained in this study. + , Positive; - , negative; $(+)$, weakly positive.

\begin{tabular}{|c|c|c|}
\hline Characteristic & $42 \mathrm{H} 12-1^{\mathrm{T}}$ & M. versicolor DSM $16678^{\mathrm{T}}$ \\
\hline Colony colour (on ISP2 at initiation) & Orange to red & Pink \\
\hline \multicolumn{3}{|l|}{ API 20 NE results } \\
\hline Urease activity & - & + \\
\hline Nitrate reduction & $(+)$ & - \\
\hline Gelatin hydrolysis & - & + \\
\hline \multicolumn{3}{|l|}{ Assimilation of (API 20NE): } \\
\hline$N$-Acetyl-D-glucosamine & - & + \\
\hline Maltose & - & + \\
\hline \multicolumn{3}{|l|}{ Enzyme activity (API ZYM) } \\
\hline$\beta$-Galactosidase & $(+)$ & - \\
\hline$\beta$-Glucosidase & + & $(+)$ \\
\hline \multicolumn{3}{|l|}{ Acid produced from (API $50 \mathrm{CH}$ ): } \\
\hline Glycerol & + & - \\
\hline D-Galactose & + & - \\
\hline D-Mannose & + & - \\
\hline D-Mannitol & + & - \\
\hline Sucrose & + & - \\
\hline Turanose & + & - \\
\hline Presence of unknown aminophospholipid & + & - \\
\hline Major fatty acids $(>9.5 \%)^{*}$ & $\mathrm{i}-\mathrm{C}_{16: 0}, \mathrm{C}_{17: 1} \omega 8 c$ & $\mathrm{i}-\mathrm{C}_{15: 0}, \mathrm{i}-\mathrm{C}_{16: 0}, \mathrm{C}_{17: 1} \omega 8 c, \mathrm{C}_{18: 1} \omega 9 c$ \\
\hline
\end{tabular}

${ }^{*}$ i, Iso-branched.

Biomass of strain $42 \mathrm{H} 12-1^{\mathrm{T}}$ and $M$. versicolor DSM $16678^{\mathrm{T}}$ for chemical and molecular analysis was prepared by culturing in liquid ISP2 broth for $3-5$ days at $28{ }^{\circ} \mathrm{C}$ in a rotary shaker and then harvesting by centrifugation.

Analysis of the isomer of diaminopimelic acid was done using freeze-dried cells, which were hydrolysed with $6 \mathrm{M}$ $\mathrm{HCl}$ at $120{ }^{\circ} \mathrm{C}$ for $30 \mathrm{~min}$ (Lechevalier \& Lechevalier, 1980). The cell hydrolysate was analysed by TLC (Hasegawa et al., 1983). Polar lipids were extracted using procedures described by Komagata \& Suzuki (1987) and separated by TLC on Merck silica gel 60 plates by two-dimensional development with polar lipid standards. Amino-group polar lipids were detected by spraying with ninhydrin and Dittmer \& Lester reagent. Menaquinones were extracted according to Collins et al. (1977) and analysed by HPLC (Kroppenstedt, 1985). Freeze-dried biomass for fatty acid analysis was prepared by culturing in tryptic soy broth (TSB; BBL) for 4 days at $28{ }^{\circ} \mathrm{C}$. Cellular fatty acid analysis was performed as described by Sasser (1990) using the Microbial Identification System (MIDI Sherlock 6.0; library TSBA6). Genomic DNA for determination of the $\mathrm{G}+\mathrm{C}$ content was prepared according to the method of Marmur (1961). The DNA $\mathrm{G}+\mathrm{C}$ content was determined by reversed-phase HPLC according to Mesbah et al. (1989).

The polar lipids detected were diphosphatidylglycerol, phosphatidylethanolamine, phosphatidylinositol, phosphatidylglycerol and an unknown aminophospholipid (Supplementary Fig. S3). The predominant menaquinone was MK-9 $\left(\mathrm{H}_{4}\right)$. The major fatty acids were iso- $\mathrm{C}_{16: 0}$ and $\mathrm{C}_{17: 1} \omega 8 \mathrm{c}$. Details of the cellular fatty acid profile are given in Supplementary Table S1.

The DIG-High Prime DNA Labelling and Detection Starter kit II (Roche) was used for DNA-DNA hybridization experiments between strain $42 \mathrm{H} 12-1^{\mathrm{T}}$ and $M$. versicolor DSM $16678^{\mathrm{T}}$. All procedures were performed in accordance with the manufacturer's directions. Detailed steps were followed as described previously (Xu et al., 2009). The DNA-DNA relatedness was $12 \%$ (SD 1.82\%).

The 16S rRNA gene sequence similarity between $42 \mathrm{H} 12-1^{\mathrm{T}}$ and M. versicolor DSM $16678^{\mathrm{T}}$ and M. multiseptatus DSM $44406^{\mathrm{T}}$ was above $97 \%$, which is the threshold that is generally recognized as delineating a genospecies (Stackebrandt \& Goebel, 1994). Characteristics such as the cell morphology, respiratory quinone system and diagnostic diamino acid in whole-cell hydrolysates indicated that the isolate should be assigned to the genus Modestobacter. A low DNA-DNA relatedness of only $12 \%$ to its closest phylogenetic relative, $M$. versicolor DSM $16678^{\mathrm{T}}$, in whole-genome association experiments and obvious phenotypic differences indicated that strain $42 \mathrm{H} 12-1^{\mathrm{T}}$ is a novel member of the genus. Strain $42 \mathrm{H} 12-$ $1^{\mathrm{T}}$ contains an unknown aminophospholipid, while $M$. versicolor DSM $16678^{\mathrm{T}}$ does not. There are obvious differences in the fatty acid profiles of the two strains (Supplementary Table S1). Phenotypic differences between the two strains are summarized in Table 1. On the basis of 
all the data, strain $42 \mathrm{H} 12-1^{\mathrm{T}}$ is proposed to represent a novel species of the genus Modestobacter, for which we propose the name Modestobacter marinus sp. nov. An emended description of the genus is also presented.

\section{Emended description of the genus Modestobacter Mevs et al. 2000}

The genus description is as given by Mevs et al. (2000) and emended by Reddy et al. (2007), with the following further modifications. The major fatty acid $(>10 \%)$ is iso- $\mathrm{C}_{16: 0}$. The DNA G $+\mathrm{C}$ content is in the range $68-73 \mathrm{~mol} \%$.

\section{Description of Modestobacter marinus sp. nov.}

Modestobacter marinus (ma.ri'nus. L. masc. adj. marinus pertaining to the sea, where the type strain was found).

Cells are non-spore-forming, Gram-stain-positive, short rods (straight, lightly curved, about $0.5-0.8 \times 1.5-2.5 \mu \mathrm{m}$; Supplementary Fig. S4), motile by means of flagella. Colonies are orange to red on copiotrophic medium at the initial stage of growth and turn black after 14 days. Colonies are dark throughout growth on oligotrophic medium. Psychrotolerant, growing at $4-35{ }^{\circ} \mathrm{C}$ (but not at $37^{\circ} \mathrm{C}$ ), with optimal growth at $28{ }^{\circ} \mathrm{C}$. Tolerant of only narrow variations in $\mathrm{pH}$, with fast growth occurring at $\mathrm{pH}$ 6-8 and very slow growth at $\mathrm{pH} 9$. Tolerates $\mathrm{NaCl}$ at concentrations less than $5 \%(\mathrm{w} / \mathrm{v})$. Hydrolyses casein, cellulose and starch. Does not produce $\mathrm{H}_{2} \mathrm{~S}$ and cannot grow on DNase test plates. In API 20NE tests, positive for aesculin hydrolysis, $p$-nitrophenyl $\beta$-D-galactopyranosidase and assimilation of L-arabinose, D-mannitol, potassium gluconate, malic acid and phenylacetate. Negative for indole production, acid from glucose, arginine dihydrolase, urease and gelatinase. Nitrate reduction is weakly positive. Tested by the API ZYM enzyme assay, positive for alkaline phosphatase, esterase lipase (C8), leucine arylamidase, valine arylamidase, acid phosphatase, naphthol-AS-BIphosphohydrolase, $\alpha$-glucosidase and $\beta$-glucosidase; weakly positive for cystine arylamidase, trypsin, $\alpha$-chymotrypsin and $\beta$-galactosidase; negative for esterase (C4), lipase (C14), $\alpha$-galactosidase, $\beta$-glucuronidase, $N$-acetyl- $\beta$-glucosaminidase, $\alpha$-mannosidase and $\alpha$-fucosidase. In the API 50 $\mathrm{CH}$ test system, acids are produced from glycerol, Larabinose, D-ribose, D-galactose, D-fructose, D-mannose, Dmannitol, aesculin, maltose, sucrose, trehalose, turanose and L-fucose. Weakly positive for acid production from Lrhamnose, salicin, cellobiose, lactose and D-lyxose. All the other API $50 \mathrm{CH}$ test results are negative. The cell-wall peptidoglycan contains meso-diaminopimelic acid as the diamino acid. Major fatty acids are iso- $\mathrm{C}_{16: 0}$ and $\mathrm{C}_{17: 1} \omega 8 c$; the major respiratory quinone is $\mathrm{MK}-9\left(\mathrm{H}_{4}\right)$. The diagnostic phospholipids are diphosphatidylglycerol, phosphatidylethanolamine, phosphatidylinositol, phosphatidylglycerol and an unknown aminophospholipid. The $\mathrm{G}+\mathrm{C}$ content of the DNA of the type strain is $72.3 \pm 1 \mathrm{~mol} \%$. Cells are sensitive to a wide variety of antibiotics, but are resistant to discs containing ceftazidime $(30 \mu \mathrm{g})$, trimethoprim $(5 \mu \mathrm{g})$ and monobactam $(30 \mu \mathrm{g})$.

The type strain, $42 \mathrm{H} 12-1^{\mathrm{T}}\left(=\mathrm{DSM} 45201^{\mathrm{T}}=\right.$ CGMCC $4.5581^{\mathrm{T}}$ ), was isolated from deep-sea sediment collected from the Atlantic Ocean.

\section{Acknowledgements}

Jun $\mathrm{Xu}$ is indebted to the China Ocean Mineral Resources Research and Development Association fund (DYXM-115-02-2-8) and the National High Technology R\&D Program of China (2007AA091904).

\section{References}

Altschul, S. F., Madden, T. L., Schäffer, A. A., Zhang, J., Zhang, Z., Miller, W. \& Lipman, D. J. (1997). Gapped BLAST and PSI-BLAST: a new generation of protein database search programs. Nucleic Acids Res 25, 3389-3402.

Cerny, G. (1978). Studies on aminopeptidase for the distinction of Gram-negative from Gram-positive bacteria. Eur J Appl Microbiol Biotechnol 5, 113-122.

Chun, J. \& Goodfellow, M. (1995). A phylogenetic analysis of the genus Nocardia with 16S rRNA gene sequences. Int J Syst Bacteriol 45, 240-245.

Chun, J., Lee, J. H., Jung, Y., Kim, M., Kim, S., Kim, B. K. \& Lim, Y. W. (2007). EzTaxon: a web-based tool for the identification of prokaryotes based on $16 \mathrm{~S}$ ribosomal RNA gene sequences. Int J Syst Evol Microbiol 57, 2259-2261.

Collins, M. D., Pirouz, T., Goodfellow, M. \& Minnikin, D. E. (1977). Distribution of menaquinones in actinomycetes and corynebacteria. J Gen Microbiol 100, 221-230.

Felsenstein, J. (1985). Confidence limits on phylogenies: an approach using the bootstrap. Evolution 39, 783-791.

Hasegawa, T., Takizawa, M. \& Tanida, S. (1983). A rapid analysis for chemical grouping of aerobic actinomycetes. J Gen Appl Microbiol 29, 319-322.

Komagata, K. \& Suzuki, K. (1987). Lipid and cell-wall analysis in bacterial systematics. Methods Microbiol 19, 161-207.

Kroppenstedt, R. M. (1985). Fatty acid and menaquinone analysis of actinomycetes and related organisms. In Chemical Methods in Bacterial Systematics, pp. 173-199. Edited by M. Goodfellow \& D. E. Minnikin. London: Academic Press.

Kumar, S., Tamura, K. \& Nei, M. (2004). MEGA3: integrated software for molecular evolutionary genetics analysis and sequence alignment. Brief Bioinform 5, 150-163.

Lechevalier, M. P. \& Lechevalier, H. A. (1980). The chemotaxonomy of actinomycetes. In Actinomycete Taxonomy (Special Publication no. 6), pp. 227-291. Edited by A. Dietz \& J. Thayer. Arlington, VA: Society for Industrial Microbiology.

Marmur, J. (1961). A procedure for the isolation of deoxyribonucleic acid from microorganisms. J Mol Biol 3, 208-218.

Mesbah, M., Premachandran, U. \& Whitman, W. B. (1989). Precise measurement of the $\mathrm{G}+\mathrm{C}$ content of deoxyribonucleic acid by high-performance liquid chromatography. Int J Syst Bacteriol 39, 159-167.

Mevs, U., Stackebrandt, E., Schumann, P., Gallikowski, C. A. \& Hirsch, P. (2000). Modestobacter multiseptatus gen. nov., sp. nov., a budding actinomycete from soils of the Asgard Range (Transantarctic Mountains). Int J Syst Evol Microbiol 50, 337-346. 
Normand, P. (2006). Geodermatophilaceae fam. nov., a formal description. Int J Syst Evol Microbiol 56, 2277-2278.

Reddy, G. S., Potrafka, R. M. \& Garcia-Pichel, F. (2007). Modestobacter versicolor sp. nov., an actinobacterium from biological soil crusts that produces melanins under oligotrophy, with emended descriptions of the genus Modestobacter and Modestobacter multiseptatus Mevs et al. 2000. Int J Syst Evol Microbiol 57, 2014-2020.

Saitou, N. \& Nei, M. (1987). The neighbor-joining method: a new method for reconstructing phylogenetic trees. Mol Biol Evol 4, 406-425.

Sasser, M. (1990). Identification of bacteria by gas chromatography of cellular fatty acids. USFCC Newsl 20, 16.

Stackebrandt, E. \& Goebel, B. M. (1994). Taxonomic note: a place for DNA-DNA reassociation and 16S rRNA sequence analysis in the present species definition in bacteriology. Int J Syst Bacteriol 44, 846-849.

Thompson, J. D., Gibson, T. J., Plewniak, F., Jeanmougin, F. \& Higgins, D. G. (1997). The CLUSTAL_X windows interface: flexible strategies for multiple sequence alignment aided by quality analysis tools. Nucleic Acids Res 25, 4876-4882.

Xu, P., Li, W. J., Tang, S. K., Zhang, Y. Q., Chen, G. Z., Chen, H. H., Xu, L. H. \& Jiang, C. L. (2005). Naxibacter alkalitolerans gen. nov., sp. nov., a novel member of the family 'Oxalobacteraceae' isolated from China. Int J Syst Evol Microbiol 55, 1149-1153.

Xu, J., Wang, Y., Xie, S. J., Xu, J., Xiao, J. \& Ruan, J. S. (2009). Streptomyces xiamenensis sp. nov., isolated from mangrove sediment. Int J Syst Evol Microbiol 59, 472-476. 